\title{
Using Student e-Portfolios to Facilitate Learning Objective Achievements in an Outcome-Based University
}

\author{
Abdallah Tubaishat and Azzedine Lansari \\ Zayed University, Abu Dhabi, UAE
}

\section{Abdallah.Tubaishat@zu.ac.ae Azzedine1@yahoo.com \\ Executive Summary}

Several researchers define e-portfolios as a digital collection of students' work accomplished throughout their time of studies in an academic program (Buzzetto-More, 2006; Love, McKean and Gathercoal, 2004; Paulson, Paulson, \& Meyer, 1991; Siemens, 2004). E-portfolios can be a rich resource for students and faculty. Students learn to identify and reflect on their learning experiences and show accomplishment of learning outcomes. Faculty members provide students with feedback and guidance to help them accomplish these learning outcomes. In this study student eportfolios consist mainly of a collection of project-based activities that provide students with opportunities to demonstrate mastery of skills and abilities. The College of Technological Innovation (CTI) has been evaluating student e-portfolios using an E-portfolio Assessment Management System (EAMS). The EAMS was developed by the University to provide students with an electronic environment to submit, get feedback, reflect and save key learning experiences. The rationale of the EAMS is to allow students to gather, store and present important projects. The students' e-portfolios are also used to demonstrate growth toward achieving specific learning outcomes to measure what students have learned and are able to do when they complete their degree program. Students start using the EAMS in semester three of their degree programs and begin the development of a working e-portfolio by archiving all major projects, their instructors' feedback as well as their reflections.

In this study, we surveyed students from the College of Technological Innovation to learn about their perception and attitude towards using e-portfolios to showcase key learning activities and to foster learning. Three major research questions guided this study: (a) Can e-portfolios facilitate student learning? (b) Can e-portfolios help students better manage their learning outcomes? and (c) Can e-portfolios help students become independent learners? A total of 165 students from the CTI College were randomly selected to take the questionnaire and 132 students ( 80 percent) agreed to participate and returned filled out questionnaires. The survey was distributed to students taking eight courses at the sophomore and junior year levels.

Material published as part of this publication, either on-line or in print, is copyrighted by the Informing Science Institute. Permission to make digital or paper copy of part or all of these works for personal or classroom use is granted without fee provided that the copies are not made or distributed for profit or commercial advantage AND that copies 1) bear this notice in full and 2) give the full citation on the first page. It is permissible to abstract these works so long as credit is given. To copy in all other cases or to republish or to post on a server or to redistribute to lists requires specific permission and payment of a fee. Contact Publisher@InformingScience.org to request redistribution permission.
Study results show that overall; students have a positive attitude and opinion towards having to use the EAMS to store their work and to document the achievement of specific learning outcomes. Students feel that they improved their learning experiences through the use of reflection. They also believe that using their e-portfolios allows them to better manage their learning. However, students did not think that they have 
become more interested in their courses or their degree program as a result of using their eportfolios. The study also found that about half the students actually enjoyed having to develop and maintain their e-portfolios to show achievement of various learning goals. Finally, as the system encourages the establishment of clear learning goals and expectations, students are taking responsibility to demonstrate that they are achieving their learning goals and faculty are helping students achieve these goals while tracking their progress towards achieving their learning outcomes.

Keywords: Electronic Portfolio, Learning Curriculum, Evaluation, Student Perspectives, Outcome -Based Higher Education

\section{E-Portfolios in Educational Institutions}

In recent years, there has been a growing interest in the use of student e-portfolios for assessing the achievements of student learning outcomes (Drost, Hanson, Molstad, Peake, \& Newman, 2008). Portfolios have been traditionally used by students in disciplines such as art and architecture as a means of collating evidence of achievements (Harun \& Cetinkaya, 2007). During, the last decade there has been a significant increase in the use of student portfolios in other disciplines such as nursing, information technology and engineering (Juwah et al., 2012). So what is an e-Portfolio? And what are the purposes and benefits of using e-portfolios by students?

Paulson et al. (1991) describe a portfolio as a meaningful collection of student work that demonstrates progress and/or mastery guided by standards and includes evidence of student selfreflection. Buzzetto-More (2006) indicates that electronic portfolios provide a unique way to document student progress, encourage improvement and motivate involvement in learning. Buzzetto-More (2006) defines portfolios as an effective form of alternative assessment that encourages students and educators to examine skills that may not be otherwise accessed using traditional means such as higher order thinking, communications, and collaborative abilities. Moreover, e-portfolios provide a framework where students are actively engaged in the learning process and become reflective learners. The benefits of reflective learning are numerous and many studies documented the impact of reflecting learning on people. Examples of these studies include a study by Mezirow (1991) on how adults learn by making meaning of their experiences, and a study by Jordi (2011) on how reflective learning can facilitate the learning process.

Several research studies have addressed the purposes and benefits of e-portfolios to students (Acker, 2012; Kellough \& Kellough, 1999; Siemens, 2004). A complete list is outside the scope of this study. Here is a brief summary listing the usefulness and benefits of student e-portfolios:

- E-portfolios are formative in nature and focus on personal development through the use of self-evaluation and reflection

- E-portfolios allow for reflections on artifacts as well as how they match goals and standards

- E-portfolios are tools to communicate with stakeholders (students, faculty, administrators, and employers)

- E-portfolios increase learning effectiveness

- E-portfolios identify students' strengths and weaknesses

- E-portfolios review, assess, and improve the effectiveness of curricular programs

- E-portfolios provide useful administrative data that will expedite decision making

- E-portfolios model professionalism, and enhances information technology skills

- E-portfolios allow for academic credits for learning beyond the classroom 
- E-portfolios can be used as an assessment tool where students are required to show how they acquire knowledge and skills through the selection of and reflection on their learning activities

- E-portfolios can be used as a tool to help career centers find jobs for students

- E-portfolios help advisors monitor student learning

- E-portfolios can be used as a tool to meet the requirements from accrediting boards

The above benefits resulted in the relatively quick adoption of e-portfolios by many educational institutions and encouraged these institutions to establish clear learning goals and expectations.

A summary of the literature shows that e-portfolios can be a great resource for both students and faculty as they can facilitate student learning and help students accomplish important learning goals. However, the above studies did not investigate how e-portfolios could be used to help students demonstrate the achievement of learning outcomes in an outcome-based academic setting, which makes this study unique.

\section{Purpose of the Study}

This study focuses on the students' attitudes and opinions towards the usefulness of e-portfolios to demonstrate achievement of learning outcomes, getting feedback from their instructors, as well as using e-portfolios as a tool to become active and reflective learners.

Three major research questions guided this study:

(a) Can e-portfolios facilitate student learning and help them achieve their learning goals?

(b) Can e-portfolios help students better manage the learning process?

(c) Can e-portfolios help students improve their learning experiences and become reflective learners?

A survey questionnaire was developed to gather data in order to find an answer to the above questions and also learn about the students' attitudes and opinions about developing and using their eportfolios to accomplish their learning outcomes.

\section{The Institution under Study}

Zayed University (ZU) is an academic public institution in the United Arab Emirates (UAE). It offers an academic program that prepares students for success in education, arts, business, media, and information technology. ZU is an outcome based institution concerned with "learning outcome assessments", how student learning and growth are measured, evaluated, and demonstrated over their years of study. Currently, the University is educating more than 8,500 male and female students from 19 countries in two campuses one in Abu Dhabi and the other in Dubai. The university endeavors to provide students learning opportunities using the American style of education and learning to ensure a quality education. The University has been accredited by the Middle States Commission on Higher Education in 2008. The majority of the faculty members have a terminal degree from North America, Europe, or Australia (Zayed University, 2012).

ZU has an excellent technology infrastructure. Its campuses are fully networked and allow students to connect to various university networks and the Internet from anywhere on campus. All the university has wired and wireless connections (classrooms, library, offices, student hubs, cafeteria, etc). Furthermore, each student is required to purchase a laptop and each faculty member receives a laptop with a three-year replacement schedule.

Students have easy access to technology in order to facilitate the learning process. Actually, ZU is known as the laptop university in this region. In the College of Technological Innovation (CTI), 
students have their own laptop loaded with the necessary software for their courses. This allows them to complete their work independently, without having to be on campus all the time. The CTI has an independent network infrastructure for teaching and research, in addition to the university's main network. This infrastructure allows students to login remotely into Linux servers to use tools needed for programming languages, databases, and web development courses. Students can also use Linux-based communication tools to collaborate with each other and with their instructors. All ZU courses are implemented on Blackboard Learn ${ }^{+}$, a learning management system. ZU students can access Blackboard Learn ${ }^{+}$from anywhere at any time using a web client service.

ZU has adopted an outcome based learning framework to provide a strong focus to the students' learning outcomes and to improve both curriculum and learning practices. The Academic Program Model (APM) was developed by faculty and emphasizes a commitment to a learner-based education and to shift the teaching paradigm to a student learning model. This model focuses on what students can actually do after they graduate. More details about this model can be found in the ZU internal report on "Self-Assessment Based on Accreditation Standards of the Middle States Commission on Higher Education", and the ZU Academic Program Model (Zayed University, 2012). The purpose of the outcome-based model is to provide students with a focused and coherent academic program and to prepare graduates for a rapidly changing and unpredictable future. It is outcome driven and uses the traditional Grade Point Average (GPA) system. The framework that constitutes the academic program model is composed of three components:

- Readiness program to ensure that students are competent in English language

- General Education

- Degree Major

A major objective of the undergraduate experience at $\mathrm{ZU}$ is the development of the skills necessary for continuous lifelong learning. The APM is designed to help achieve this objective by providing students with a foundation and framework for all university studies. Every ZU course focuses on one or more of the six university-specified learning outcomes. The learning outcomes are incorporated into normal course work and, therefore, are an integral part of disciplinary content and evaluation of the course. Threaded throughout the baccalaureate curriculum, the learning outcomes help students achieve a higher order of intellectual development. ZU has six graduation requirements, called Zayed University Learning Outcomes (ZULOs), for all students regardless of their major. These requirements are depicted in Table 1 (Zayed University, 2012):

\begin{tabular}{|l|l|}
\hline \multicolumn{2}{|c|}{ Table 1: Zayed University Learning Outcomes } \\
\hline Learning Outcome & Description \\
\hline $\begin{array}{l}\text { Information Literacy and } \\
\text { Communication }\end{array}$ & $\begin{array}{l}\text { ZU graduates will be able to recognize information needs, } \\
\text { access and evaluate appropriate information to answer } \\
\text { those needs, and communicate effectively to a variety of } \\
\text { audiences in both English and Arabic. }\end{array}$ \\
\hline Information Technology & $\begin{array}{l}\text { ZU graduates will be critically aware of the implications of } \\
\text { information technology on the individual and on society } \\
\text { and be able to use IT to communicate and solve problems } \\
\text { in an ethical way. }\end{array}$ \\
\hline $\begin{array}{l}\text { Critical Thinking and } \\
\text { Quantitative Reasoning }\end{array}$ & $\begin{array}{l}\text { ZU graduates will be able to use information, reasoning, } \\
\text { and creative processes to achieve goals and make responsi- } \\
\text { ble decisions. }\end{array}$ \\
\hline
\end{tabular}




\begin{tabular}{|l|l|}
\hline Global Awareness & $\begin{array}{l}\text { ZU graduates will be able to relate to communities beyond } \\
\text { the local, perceive and react to differences from an infor- } \\
\text { mal and reasoned point of view, and be critically aware of } \\
\text { the implications and benefits of cultural interaction. }\end{array}$ \\
\hline Teamwork and leadership & $\begin{array}{l}\text { ZU graduates will be able to work efficiently and effective- } \\
\text { ly in a group. ZU graduates will be able to assume leader- } \\
\text { ship roles and responsibilities in a variety of life situations } \\
\text { and accept accountability for the results. }\end{array}$ \\
\hline Bilingual & $\begin{array}{l}\text { ZU graduates will be able to communicate effectively (oral } \\
\text { and written) in both English and Arabic. }\end{array}$ \\
\hline
\end{tabular}

\section{Outcome-Based Computing Curriculum}

Student learning outcomes have become the focus of many universities as a way to measure and document student learning (Chambers \& Wickersham, 2007). Chambers and Wickersham (2007, p. 352) indicated that "these outcomes measure how a student's university experience has supported their development as individuals and describes the knowledge, skills, abilities and attitudes students are able to demonstrate upon completion of a program." Furthermore, the methods by which these learning outcomes are assessed to determine student success of learning expectations vary and may be dependent upon the course, program, and/or assessment practices and beliefs of the faculty.

The Information Technology program under study strives to meet the demands of government and industry in the UAE technology market. This cooperative process usually includes advisory boards, called National Advisory Council (NAC), where industry leaders communicate the technical needs to faculty and administrators. Currently, the CTI offers three tracks: Security and Networking, Enterprise Computing, and Multimedia Design. All core courses in each sequence include specific university learning outcomes (ZULOs) and specific major learning outcomes (MALOs) that are applicable to the courses contents. The college programs have been accredited by the Accreditation Board for Engineering and Technology (ABET http://www.abet.org) in 2010.

The CTI has established six learning outcomes that complement the learning outcomes of the Academic Program Model (see Table 2). These major learning outcomes form the basis for analysis and assessment that play an essential role in the continuous process of improvement.

\section{Table 2: Major Learning Outcomes for the College of Technological Innovation}

\begin{tabular}{|l|l|}
\hline Learning Outcome & Description \\
\hline $\begin{array}{l}\text { Critical Thinking and Quanti- } \\
\text { tative Reasoning in IT }\end{array}$ & $\begin{array}{l}\text { IT College graduates will be able to use critical thinking } \\
\text { and quantitative processes to identify, analyze and solve } \\
\text { problems, and evaluate solutions in an IT context. }\end{array}$ \\
\hline $\begin{array}{l}\text { Information Technology Ap- } \\
\text { plication }\end{array}$ & $\begin{array}{l}\text { IT College graduates will be able to select existing and } \\
\text { cutting-edge IT tools and procedures to develop modules } \\
\text { and systems. }\end{array}$ \\
\hline $\begin{array}{l}\text { Information Technology } \\
\text { Management }\end{array}$ & $\begin{array}{l}\text { IT College graduates will be able to assess and determine } \\
\text { information resource requirements to develop solutions } \\
\text { suitable for IT and business managers operating in a multi- } \\
\text { national and multi-cultural environment. }\end{array}$ \\
\hline
\end{tabular}




\begin{tabular}{|l|l|}
\hline $\begin{array}{l}\text { Information Technology Pro- } \\
\text { fessional Practice }\end{array}$ & $\begin{array}{l}\text { IT College graduates will be able to work effectively in } \\
\text { individual and group situations, understand how groups } \\
\text { interact, be able to assume a leadership role when re- } \\
\text { quired, and understand the fundamentals of professional } \\
\text { and ethical conduct. }\end{array}$ \\
\hline $\begin{array}{l}\text { Information Technology Sys- } \\
\text { tems Theory and Practice }\end{array}$ & $\begin{array}{l}\text { IT College graduates will be able to understand and com- } \\
\text { municate the fundamentals of systems theory in the devel- } \\
\text { opment of appropriate systems that function in a global } \\
\text { environment. }\end{array}$ \\
\hline $\begin{array}{l}\text { Technical Communication } \\
\text { (Bilingual) }\end{array}$ & $\begin{array}{l}\text { IT College graduates will be able to express themselves } \\
\text { effectively and efficiently in both English and Arabic } \\
\text { while using the correct IT terms for each language. }\end{array}$ \\
\hline
\end{tabular}

\section{E-Portfolio Assessment Management System}

The e-Portfolio Assessment Management System (EAMS) was developed in 2007 to help faculty assess student learning outcomes and evaluate how courses and College programs are meeting institutional goals. The system is described in detail in a previous journal paper (Tubaishat, Lansari, \& Alrawi, 2009). The system is an e-learning system that focuses on knowledge representation and learning by reflection. It is a repository management system that facilitates collecting, sharing, and presenting artifacts of student learning outcomes via a digital medium. The system is introduced to students early in their courses to give them time to learn and understand how to upload, and reflect on their e-portfolio artifacts. All artifacts are carefully selected by the students to showcase their best work. This process allows them to demonstrate what they have actually learned and helps them reflect upon the learning process.

The system was built around two predefined set of learning outcomes:

- An institutionally agreed upon set of student learning outcomes, ZULOs, listed in Table 1. - Learning outcomes that are related to the major's requirements, MALOs, listed in Table 2.

The EAMS is a web-based e-portfolio management system developed by the university. The rationale of the EAMS is to allow students to collect key courses learning items that represent their accomplishment towards the satisfaction of the learning outcomes using a pedagogical web-based environment. The hope is for students to become more focused learners as well as promote responsibility and ownership in the learning process; and ultimately becoming lifelong learners. The drive for the implementation of the EAMS came from two components within our institution: the first is the University's commitment to the proper implementation of the learning outcomes by making sure that they should be included in courses at various levels of achievement (Beginning, Developing, and Accomplished). The second driving force is the ABET accreditation body, which requires the university to showcase evidence of learning achievements against the chosen professional skills criteria.

The purposes of the EAMS can be summarized as follows:

- To show student growth and change over time

- To allow student input into the learning process

- To track the development and course integration of learning outcomes (MALOs, ZULOs)

- To measure how students accomplish their MALOs

- To provide an opportunity for students and faculty members to discuss learning outcomes and the progress toward achieving institutional goals (ZULOs)

- To measure student's performance based on samples of their work

- To help students learn/develop self-evaluation 


\section{How Does the EAMS Work?}

The EAMS is an important resource used in all Colleges for various assessment activities. The system includes a searchable, electronic storage area where specific examples of student work are uploaded from their courses. Students regardless of their major start using the EAMS in semester three of their degree program and therefore begin the development of a working e-portfolio by archiving projects and other assignments, as well as their instructor's feedback and reflections during early courses.

In each course in the Information Technology concentrations, faculty members are required to include assignments designed to assess one or two of the six MALOs presented in Table 2. Because the e-portfolio assignments are the key component to the success of the learning outcomes assessment process, faculty members are encouraged to design assignments that provide students with an opportunity to demonstrate their most distinguished performance and scholarly accomplishments. Examples of appropriate e-portfolio assignments include a term paper, a project work, a programming assignment, or a network design. Faculty members are required to provide a criteria sheet for each portfolio assignment that explains the purposes and the learning objectives assessed. After reviewing their students' work faculty members comment on the work and post their feedback in a designated area of the EAMS. Moreover, faculty members evaluate both the assignment's general effectiveness and its level of accomplishment with respect to the desired outcome(s). Students are then able to access the faculty comments from the EAMS, as well as any other work posted on the system. This process enables students to update their work and reflect on their learning experience.

The EAMS was designed to function as an archive for research on the effectiveness of various courses in achieving learning outcomes. Because all major student work is uploaded to the EAMS system, research into student achievement of learning outcomes in specific courses or sequences of courses can be easily carried out. Furthermore, all student work can be sorted and studied either by course or by learning outcome. The CTI has accumulated a significant amount of data from the EAMS to evaluate students' achievements towards the accomplishment of their chosen learning outcomes.

Figure 1 shows the EAMS interface. The interface shows, for a particular faculty member, the courses being taught as well as the assessment criteria posted by the instructor. It allows him/her to select the term code and the courses in that semester through accessing e-portfolio systems via the Intranet or extranet.

After matching courses with learning outcomes, faculty members develop key assignments for the courses to optimize their learning target. The assignments may include a major term paper, a lab exercise, a design for building a network, or a case study. Figure 2 shows another snapshot of the EAMS for an e-portfolio course (CIT490) with committee member names, learning outcomes, and assessment criteria used in this course. After grading the piece of evidence, the instructor posts the assessment feedback. The students can then access the instructor's feedback and modify their work as needed. Finally, the students have the option to include that piece of evidence as an artifact in their e-portfolio. 


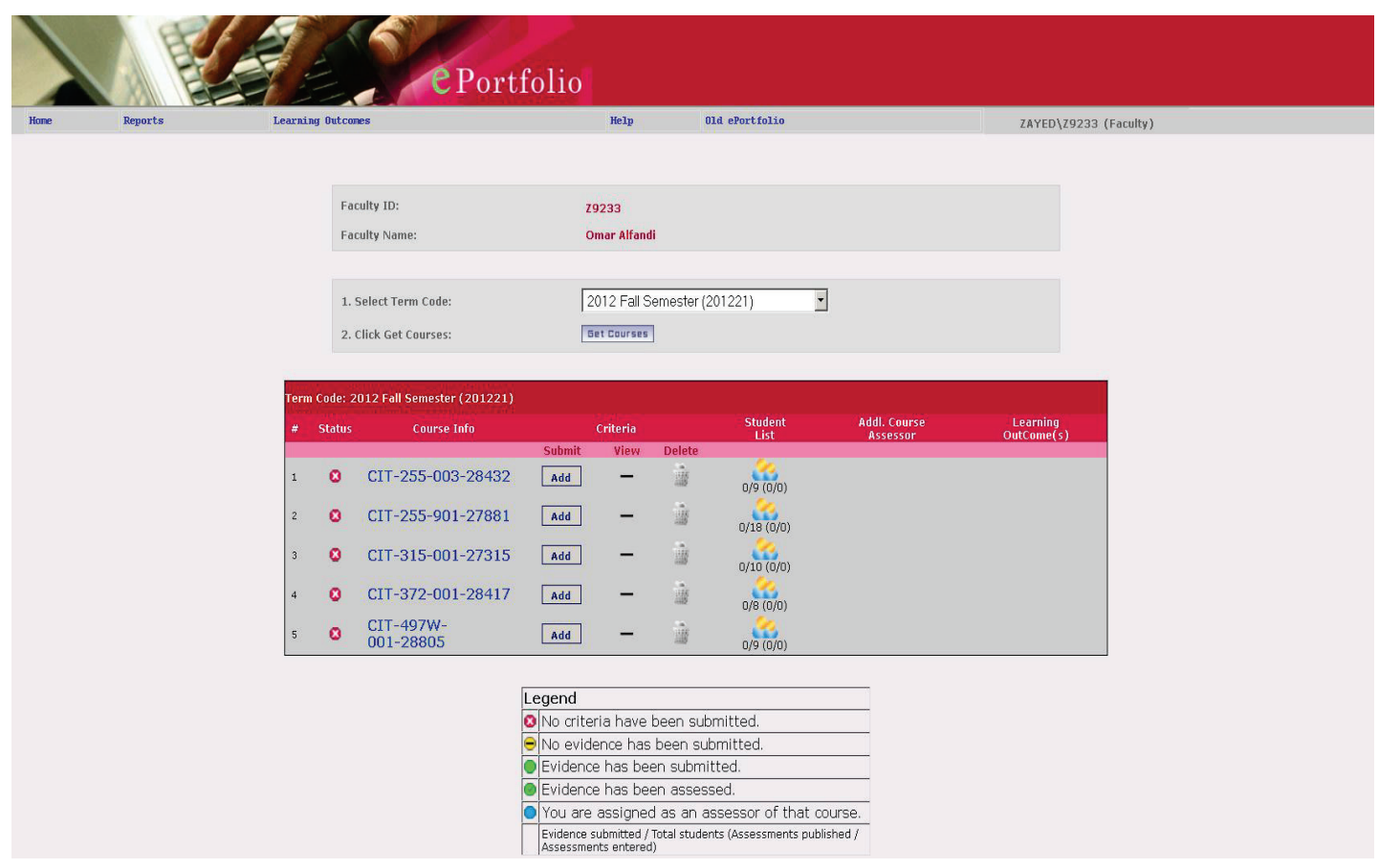

Figure 1: E-portfolio Assessment Management System Interface 


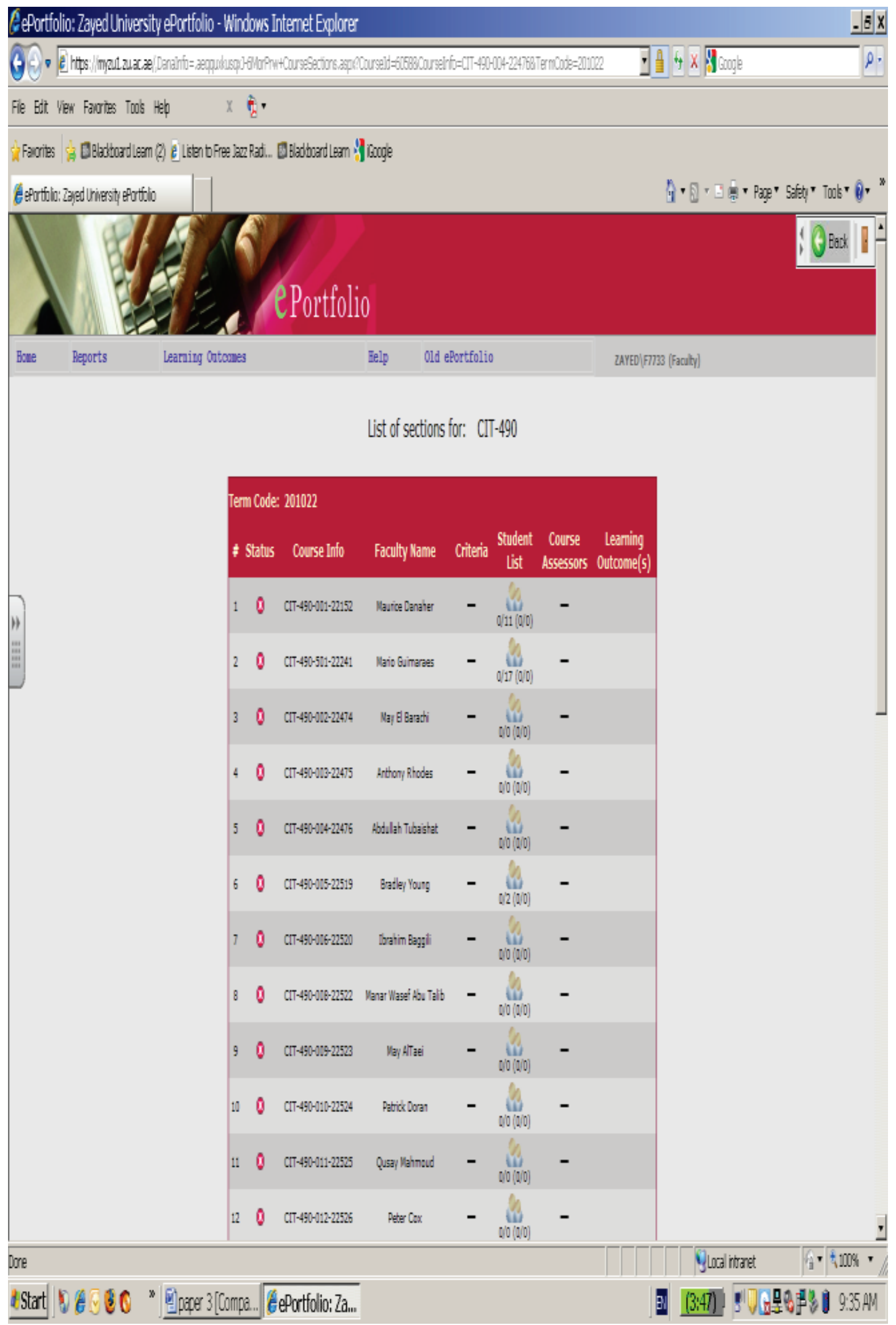

Figure 2: E-Portfolio Course Information, Committee Members, Learning Outcomes and Assessment Criteria 


\section{Case Study}

\section{Objective of the Study}

The purpose of this study is to investigate the effectiveness of using e-portfolios to help Information Technology students in the CTI College select, reflect and organize key learning experiences to demonstrate the achievement of their learning outcomes. The study also investigates the student's impression on the usefulness of e-portfolios as a tool to help them plan and achieve their courses and learning goals.

\section{Study Participants}

A total of 165 students from the College of Technological Innovation (formerly College of Information Technology), which uses an outcome-based academic curriculum, were randomly selected for taking part in a survey study. The total number of students selected for this study included 127 females and 38 males. However, only 132 students (about 80 percent of the selected students) agreed to participate in the study and filled out the questionnaire on time. The survey questionnaire was distributed to students participating in the following courses: CIT210 (Introduction to IT and Systems, CIT215 Computing Foundations, CIT245 (Web Development), CIT255 (Network and Telecommunication), CIT320 (Programming and Problem Solving), CIT335 (Information Security Technologies), CIT360 (Management of Information Systems), and CIT372 (Cloud Computing). The variety in course selection was based on the idea that courses should cover a variety of topics and be from different levels of study in this case from the sophomore and junior years.

\section{Questionnaire Data Collection and Analysis}

A structured one page questionnaire was designed to survey and collect data from sophomore and junior students, both male and female. The survey questionnaire consisted of seven Likert scale response questions. The questionnaire was made up of twelve closed-ended questions with five multiple choices (Strongly Disagree, Disagree, Undecided, Agree, Strongly Agree). Students completed the questionnaire during the Spring semester of 2012. Prior to distributing the questionnaire, ethical approval to conduct the study was obtained from the university. Below are the survey statistics and data analysis of the survey results. Table 3 shows all the questions with the analysis of data.

\begin{tabular}{|c|c|c|c|c|c|}
\hline \multicolumn{6}{|c|}{ Table 3: Survey Questions and Statistics } \\
\hline Category / Questions & Ans & wer & & & \\
\hline Learning Domain & SD & $\mathbf{D}$ & $\mathbf{U}$ & $\mathbf{A}$ & SA \\
\hline My e-portfolio helps me improve my learning experiences & 4.8 & 10.3 & 24.7 & 44.2 & 16 \\
\hline $\begin{array}{l}\text { My e-portfolio helps me decide what I need to do to } \\
\text { achieve my learning goals }\end{array}$ & 1.8 & 14.5 & 27.3 & 43.9 & 12.5 \\
\hline $\begin{array}{l}\text { My e-portfolio has made me more interested in my degree } \\
\text { program }\end{array}$ & 4.2 & 13.3 & 33.3 & 33.4 & 15.8 \\
\hline My e-portfolio makes me more interested in courses & 2.4 & 20 & 37.6 & 33.3 & 6.7 \\
\hline $\begin{array}{l}\text { My e-portfolio helps me decide which courses to take to } \\
\text { achieve my learning goals }\end{array}$ & 4.2 & 17.6 & 36.4 & 32.7 & 9.1 \\
\hline
\end{tabular}




\begin{tabular}{|l|l|l|l|l|l|}
\hline My e-portfolio has been fun to put together & 1.8 & 12.7 & 30.3 & 41.2 & 14 \\
\hline $\begin{array}{l}\text { My e-portfolio allows me to get better feedback on my } \\
\text { work }\end{array}$ & 3.6 & 5.5 & 15.6 & 50.9 & 24.4 \\
\hline My e-portfolio helps me to reflect on my work & 4.8 & 3.6 & 15.2 & 49.8 & 26.6 \\
\hline $\begin{array}{l}\text { My e-portfolio helps me monitor my progress towards } \\
\text { achieving goals in my degree program }\end{array}$ & 2.4 & 7.9 & 24.8 & 50.1 & 14.8 \\
\hline $\begin{array}{l}\text { My e-Portfolio helps me use feedback from my teachers to } \\
\text { improve my work }\end{array}$ & 2.4 & 11.5 & 17.6 & 41.2 & 27.3 \\
\hline $\begin{array}{l}\text { My e-Portfolio helps me become better organized in my } \\
\text { work }\end{array}$ & 2.4 & 7.9 & 19.3 & 48 & 22.4 \\
\hline $\begin{array}{l}\text { My e-Portfolio has helped me plan and improve my learn- } \\
\text { ing experiences }\end{array}$ & 1.8 & 13.9 & 20.6 & 45.9 & 17.8 \\
\hline
\end{tabular}

\section{Student Response and Data Analysis}

A survey questionnaire was developed to gather data to try to find an answer to the above questions and also learn about the student's attitudes and opinions about developing and using eportfolios: Twelve questions were developed to gather the data needed to answer the research questions. Table 4 shows all the questions with the respective students' responses and analysis.

\section{Table 4: Questionnaire Response Analysis}

1. My e-portfolio helps me improve my learning experiences: The first question in the questionnaire was designed to learn about the overall students' perception on the use of an eportfolio toward improving their learning experience. More than half the students either agreed or strongly agreed that the use of e-portfolios have helped them improve their learning. About 15 percent either disagreed or strongly disagreed with the statement that their eportfolios have helped them improve their learning. A quarter of the students were unsure whether e-portfolios helped them or not.

2. My e-portfolio helps me decide what I need to do to achieve my learning goals: The second question was designed to learn whether using e-portfolios has helped students make decisions to reach or achieve their learning goals. More than half the students either agreed or strongly agreed (56 percent). About a quarter of the students ( 27 percent) was undecided as to whether e-portfolios helped them achieve their learning goals and 16 percent either disagreed or strongly disagreed that using e-portfolios helped them achieve their learning goals.

3. My e-portfolio has made me more interested in my degree program: The third question was designed to learn whether through the use of e-portfolios students became more interested in their degree program. Less than half (49 percent) strongly agreed or agreed with that statement. One third ( 33 percent) were undecided and about 18 percent either disagreed or strongly disagreed that using e-portfolios made them more interested in their degree program.

4. My e-portfolio makes me more interested in courses: The fourth question was designed to learn about the relationship between the use of e-portfolios and the students' interest in the courses they took. Only 6.7 percent seemed to strongly agree and 33 percent responded with agree to that question. About 38 percent were undecided and a little less than a quarter (22 percent) either disagreed or strongly disagreed with the statement that their eportfolios made them more interested in their courses. 
5. My e-portfolio helps me decide which courses to take to achieve my learning goals: The fifth question was designed to learn whether using e-portfolios helped students decide which courses they need to take to achieve their learning goals. Only 42 percent agreed or strongly agreed to that statement. More than one third of the students (36 percent) were undecided and 22 percent either disagreed or strongly disagreed with that statement.

6. My e-portfolio has been fun to put together: The sixth question was designed to learn about the student's attitude and willingness towards building and using the e-portfolio. More than half the students ( 55 percent) either agreed or strongly agreed. About a third ( 30 percent) were unsure about that statement and about 15 percent either disagreed or strongly disagreed to having fun while developing their e-portfolios.

7. My e-portfolio allows me to get better feedback on my work: The seventh question was designed to learn about the student's opinion on whether they received better instructor feedback using their e-portfolio. More than 75 percent of the students either strongly agreed or agreed that the use of e-portfolios helps them get better feedback from the instructors. Around 16 percent of the students were undecided about that perception and only 9 percent disagreed or strongly disagreed about the fact that e-portfolios allow get to get better feedback from their instructors.

8. My e-portfolio helps me to reflect on my work: The eighth question was designed to learn about the possibility that e-portfolios can help students in their reflections after receiving the instructor's feedback on their posted work. More than 76 percent of the students responded by either agree or strongly agree to the fact that the use of their e-portfolio helped them in reflecting on their work. About 15 percent were undecided and 9 percent either disagreed or strongly disagreed that using their e-portfolios helped them reflect on their work

9. My e-portfolio helps me monitor my progress towards achieving goals in my degree program: The ninth question was designed to learn about the student's impression from the use of the e-portfolio to help them monitor their progress towards achieving their learning goals in their degree program. About 65 percent of the students either agreed or strongly agreed to that statement, 25 percent were undecided whether their e-portfolio helped them monitor their progress towards achieve their goals. Around ten percent disagreed or strongly disagree to that statement.

10. My e-Portfolio helps me use feedback from my teachers to improve my work: The tenth question was designed to learn about the possibility that the e-portfolio platform helped students receive instructor feedback to plan and/or improve their learning experiences. These experiences usually are the student's key pieces of evidence towards achieving learning outcomes. About 69 percents agreed or strongly agreed to that statement, about 18 percent were unsure or undecided and about 14 percent either disagreed or strongly disagree to the fact that their e-portfolios could help towards that goal.

11. My e-Portfolio helps me become better organized in my work: The eleventh question was designed to learn whether the use of e-portfolios can facilitate the process of selecting and organizing the students' most significant work. About 70 percent of the students responded positively by choosing agree or strongly agree. Around 19 percent were undecided and 10 percent chose either disagree or strongly disagree as their choice of answer.

12. My e-Portfolio has helped me plan and improve my learning experiences: The twelfth question of the questionnaire was designed to learn about the overall usefulness of the e-portfolio as a planning tool to optimize students learning experiences. Almost 64 percent of the students responses to the question were either agree or strongly agree. Almost 21 percent of the students were undecided and almost 16 percent chose either disagree or strongly disagree that their e-portfolios help them plan and improve their learning experiences. 


\section{Data Analysis Summary}

The analysis of the survey data shows that more than half the students (Q1: $60 \%$, Q12: $64 \%$ ) believe (agree or strongly agree) that using e-portfolios helped them improve their learning experiences. Students also agreed with the fact that their e-portfolios help them get feedback from their instructors thus helping them improve their work (Q10: 69 \%), they help them reflect on their work (Q8: $76 \%$ ), and students believe that e-portfolios help them monitor progress towards achieving their learning goals (Q9: 65\%). Therefore the answer to the first two questions of this study "can e-portfolios facilitate student learning and help them achieve their learning goals" and "can e-portfolios help students better manage the learning process" the answer is positive.

On the other hand, only half the students think that using e-portfolios have actually helped them become more interested in their degree program (Q3: 49\%) or their courses for that matter $(\mathrm{Q} 4$ : $40 \%$ ). Furthermore e-portfolios did not seem to significantly help students decide which courses to take to achieve their learning goals (Q5: 42 percent). Therefore the answer to the third question of this study "can e-portfolios help students improve their learning experiences and be reflective learners" is still unclear. Finally, as to whether students had fun putting together their eportfolios about half of the students agreed to that statement (Q6: $55 \%$ ) and about a third were undecided (30\%).

\section{Conclusions}

An outcome-based university in the gulf region uses an academic program built around two sets of learning outcomes: an institutionally agreed upon set and a College specific set. Furthermore, the university has recently developed an e-portfolio assessment management system (EAMS) to allow Colleges to document and assess important student work, provide them with feedback on their work, and track the students' learning outcomes achievements. The system is an electronic repository management system that facilitates collecting, sharing, and presenting students work. Students are encouraged to use their e-portfolios to gather and analyze their most significant work.

In this study, 165 students were randomly selected for the distribution of a research questionnaire to learn about the students opinions on the usefulness of their e-portfolios as a tool to enhance their learning experiences. About 80 percent of the selected students (132) agreed to take part in this study and filled out the questionnaire. The survey was distributed to students in eight courses across the sophomore and junior years of the CTI academic program. Analysis of the questionnaire responses showed that the majority of the students value their e-portfolios and believe that using their e-portfolios actually helps them achieve their learning objectives. They also believe that their e-portfolios (via the EAMS) allow them to receive the instructor's feedback quickly. This allows them to improve their work and monitor their progress toward achieving their learning goals.

Students however, did not seem to think that the use of e-portfolios made them more interested in their courses and degree program. Moreover, the use of e-portfolios did not help them decide which courses they needed to take to achieve their learning goals. Therefore, the faculty advisor has still an important role in that respect. Finally, only about half the students seemed to actually enjoy developing and using their e-portfolios. This may be due to the fact that some students feel they spend too much time in the process of keeping up and updating their e-portfolios.

The use of outcome-based curricula and students' e-portfolios to foster learning is still at an early stage in the UAE and the Gulf region. In the CTI College both students and instructors are learning how to best use e-portfolios to achieve key learning goals. The next step in this research is to learn whether the use of the E-portfolio Assessment Management System will help move both 
instructors and students towards a better teacher/learner relationship where the instructor's guidance is more effective.

\section{References}

Acker, S. (2012). Technology-enabled teaching/elearning dialogue: Overcoming obstacles to authentic ePortfolio assessment. Retrieved June 25, 2012 from Campus Technology Web-site: http://www.campus-technology.com/news_article.asp?id=10788\&typeid=155.

Buzzetto-More, N. (2006). The e-Learning and business education paradigm: Enhancing education, assessment, and accountability. Proceedings of the Maryland Business Education Association Conference. Ocean City, MD, 2006.

Buzzetto-More, N.. \& Alade, A. (2006). Best Practices in e-Assessment. Journal of Information Technology Education. 5(251-269). Retrieved from http://www.jite.org/documents/Vol5/v5p251269Buzzetto152.pdf

Chambers, S., \& Wickersham, L. (2007). The electronic portfolio journey: A year later. Education Journal, $127(3), 351-360$.

Drost, D., Hanson, L., Molstad, C., Peake, L., \& Newman, E. (2008). Outcome assessment of a management program using a portfolio approach: Lessons learned. American Journal of Business Education, Fourth Quarter, 1(2), 105-111.

Harun, Y., \& Cetinkaya, B. (2007). Using an online portfolio course in assessing students' work. Turkish Online Journal of Educational Technology, 6(4), 1-6.

Jordi, R. (2011). Reframing the concept of reflection: Consciousness, experiential learning, and reflective learning practices. Adult Education Quarterly, May, 61(2), 181-197.

Juwah, C., Macfarlane-Dick, D., Matthew, B., Nicol, D., Ros, D., \& Smith, B. (2012). Enhancing student learning through effective formative feedback. Retrieved Sept. 12, 2012 from http://www.heacademy.ac.uk/assets/documents/resources/database/id353_senlef_guide.pdf

Kellough, R. D., \& Kellough, N. G. (1999). Secondary school teaching: A guide to methods and resources; planning for competence. Upper Saddle River, New Jersey Prentice Hall.

Love, D., McKean, G., \& Gathercoal, P. (2004). Portfolios to webfolios and beyond: Levels of maturation. Educause Quarterly, 27(2). Retrieved from https://www.educause.edu/library/eqm0423

Mezirow, J. (1991). Transformative dimensions of adult learning. San Francisco, CA: Jossey-Bass.

Paulson, F. L., Paulson, P. R., \& Meyer, C. (1991). What makes a portfolio a portfolio? Educational Leadership, 48(5), 60-63.

Siemens, G. (2004). ePortfolios. eLearnSpace: Everything ELearning. Retrieved September 11, 2012 from http://www.elearnspace.org/Articles/eportfolios.htm

Tubaishat, A., Lansari, A., \& Alrawi, A. (2009). E-portfolio assessment system for an outcome-based information technology curriculum. Journal of Information Technology Education: Innovations in Practice, 8, 43-54. Retrieved from http://www.jite.org/documents/Vol8/JITEv8IIP043054Tubaishat710.pdf

Zayed University. (2012). The Academic Program Model. Available at http://www.zu.ac.ae. 


\section{Biographies}

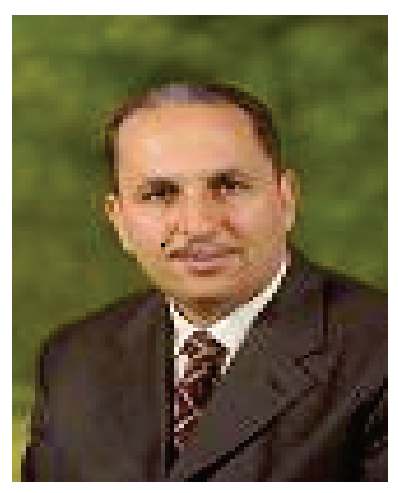

Abdallah Tubaishat is an Associate Professor in the College of Technological Innovation at Zayed University, United Arab Emirates. He received his $\mathrm{PhD}$ in Software Engineering from Illinois Institute of Technology, IL, USA in 1994. Dr. Tubaishat has fifteen years of experience in teaching and research. His teaching experience include: Software Engineering, Database and Programming, His research interests include software engineering and educational technology. He has published a book with others entitled "Computer Skills", and has around twenty three Journal and conference publications.

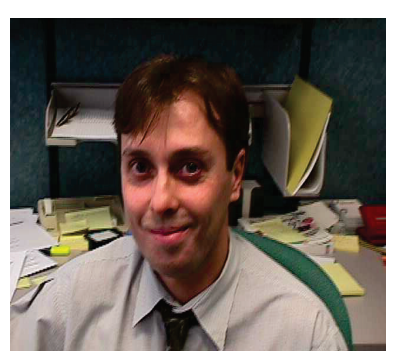

Azzedine Lansari received a $\mathrm{PhD}$ in Bioengineering from North Carolina State University in 1992. From 1992-1998, he was a senior researcher at Computer Sciences Corp. and MANTECH, Inc. He joined Zayed University in August 1998, and was promoted to Associate Professor of Information Technology in 2007. He has been living in the USA since 2010. His teaching interests include: Computing foundations and statistical modeling. His research interests include systems modeling, educational technology and curriculum design. 